\title{
Investigating the Effect of Planned Organizational Changes on Professional Development and Empowerment of the Employees of Physical Injuries Compensation`Fund
}

\author{
Shabnam Akbarzadeh Ghaleh*, Maryam Heydari \\ MA, Department of Governmental Management, \\ South Tehran Branch, Islamic Azad University, Tehran, Iran \\ e-mail $\bowtie$ akbarzade.50@gmail.com
}

\begin{abstract}
The present study aimed to investigate the effect of planned organizational changes on professional development and empowerment of the employees of the physical injuries compensation fund. This research was applied in terms of purpose and it was descriptive-correlational in terms of methodology. The statistical population of this study included all the employees of the physical injuries compensation fund in Tehran (252 individuals). Stratified sampling method was used in this research. The Morgan Table was used to determine the sample size that according to this table, the statistical sample included 148 individuals. The present research was conducted in two parts of theoretical and practical parts. In the theoretical part, the required information was obtained using the library and documentary method. In the practical part, the field research method and standard questionnaires were used to collect data. Data were analyzed using SPSS software and multivariate and simple regression tests. The findings of the research indicated that planned organizational changes and its three dimensions (developmental change, transitional change, and transformational change) had a significant effect on the professional development and empowerment of employees of the physical damage compensation fund.
\end{abstract}

Keywords: Planned Organizational Changes, Professional Development, Empowerment, Physical Injuries Compensation Fund

\section{Introduction}

Nowadays, human resources are considered as the most important resources of the organizations and managers are well understood that the most important factor in gaining a competitive advantage is the human resources of the organization. Therefore, paying attention to the employees' ability and capability and also professional and job performance of human resources to the organization and better performance of the assigned tasks and even the extraordinary tasks by the human resources are one of the important concerns of the organizations' managers ( Majidi, 2008).

Hence, with regard to physical injuries compensation fund and also other organizations with similar goals, one of the important factors that can contribute to their advancement is the employees' empowerment. Empowerment is the process of empowering the individuals. In this process, we help our employees to improve their self-confidence and overcome the feelings of inability and helplessness. Empowerment in this sense mobilizes individuals' intrinsic motivations (Nobkht et al., 2013).

Providing professional development programs is one of the most effective ways to empower employees that can promote a person's professional and scientific skills and also his organizational commitment. Therefore, empowering employees for professional development and promotion of the organization's goals is of crucial importance and it requires purposeful planning and institutionalized efforts (Hejazi et al., 2011).

The physical injuries compensation fund is an organization whose role of human resources and professional capability and performance is really important. This organization is an independent fund whose purpose is to support injured people who cannot have their compensation payment through insurance and whose losses remain unaffordable. If the fund and its human resources fail to fulfill their organizational goals of protecting the injured people who cannot be compensated through the insurance, it is not only departed from the fund's own existence philosophy, but also have imposed double damages on the injured people. In protecting those people, if the organization and employees without the required capability and professional development take the responsibility, they may not be able to achieve the desired results. Employees of such organizations in relation to organizational affairs and goals must be capable and professional as much as necessary to properly identify the damaged people and take the necessary measures to reduce the damage caused by the loss. Hence, according to the importance of 
changes and planning for the provision of organizational goals and also their role in physical injuries compensation fund, the planned organizational changes can be used in physical injuries compensation fund for the professional development and empowerment of its employees. Therefore, this study sought to examine the role of planned organizational changes on professional development and empowerment of employees of physical injuries compensation fund and determine whether the planned organizational changes and its dimensions and components have a significant effect on the professional development and employees' empowerment of physical injuries compensation fund.

\section{Research Background}

The empowerment of employees is the set of systems, methods and measures that are employed to develop the capabilities and competencies of individuals in order to improve and enhance the productivity, growth, and prosperity of the organization and human resources in accordance with the organization goals (Carter, 2001). In addition, the operational implication of each of the variables includes: the organizational planned changes regarding which, a questionnaire containing the components of transformational change, transitional change, and developmental change was used to operationalize organizational changes (Anderson, Ackerman, 2010).

The most important step in the process of empowering employees is to provide an environment that makes an opportunity for individuals to practice a degree of authority and power and make inner motivation within the employees. Many studies regarding the empowerment have shown that the environment provides opportunities for employees. Hence, empowered environments make opportunities and disempowered environments make limitations to the employees. However, it depends on the degree of influence that is applied on working outcomes. If the employees are capable but not yet sufficiently influential, they are without the probable impact of opportunity or environmental support. In other words, this sense must be created to the employees that they are supported in order to effectively provide opportunities to be impressed. Organizational commitment has a significant relationship with empowerment and independence is an important factor in trust building and trust makes high risk-taking since most of the positive organizational changes are due to the trust between managers and employees. The delegation creates a sense of self-directedness in individuals and makes and initiatives their behaviors and work processes (Robbins et al., 2002).

Tayebi Shirmard and Mirzaei (2018) in a study entitled "examining the relationship between organizational structure and the empowerment of employees of Tehran Municipality Management Development Department", showed that there is a significant relationship between exiting organizational structure and psychological empowerment of employees; there is a significant relationship between formalization and employees empowerment of Tehran Management Deputy; there is a significant relationship between concentration and empowerment of Tehran Management Development Deputy; the results of testing the hypothesis showed that the component of complexity in the dimensions of organizational structure has no significant relationships with the empowerment of employees.

Roshanfekr and Daneshfard (2015) in a study examined the relationship between planned organizational changes and empowerment of Yasuj University employees and showed that the formal and complexity factors are significant at $99 \%$ level. An increase in the score of each of these factors can increase the empowerment at the university. The result also showed that the two factors of hierarchy and authority had no significant relationships with the empowerment of Yasuj University employees.

Vaezi and Sabzikaran (2010) in a study regarding the relationship between organizational changes and employees' empowerment at National Iranian Oil Products Distribution Company (NIOPDC)-Tehran showed that the correlational relationship between organizational changes variable and psychological empowerment is significant and these two variables are related to each other.

The findings of Cares et al. (2017) indicated that managers (in non-profit organizations) need to be highly empowerment and creative in the profession since the organizational changes variables are more important. The findings of the research suggested that managers with high professional creativity are often more able to accommodate organizational changes and achieve the empowerment.

Aron (2013) pointed to the positive and significant relationship between management factors in an organization and professional development. In fact, management factors in an organization can enhance the sense of value, sense of difference and organizational attention in employees. When these supports are accompanied with opportunities to develop skills, job abilities, decision-making freedom, and using initiatives that are more relevant to professional development will result in increased job satisfaction and professional development for the organization. 


\section{Reserach Methodology}

The present research was applied in terms of purpose and was descriptive-correlational in terms of methoology that the required information has been collected by library and survey method (questionnaire). Since the samples have been used to generalize the findings to the society and make inferences, this research was considered an inferential study. This research was performed with the purpose of examining the role of planned organizational changes on the professional development and empowerment of employees' physical injuries compensation fund.

The statistical population of this study included all employees Tehran Physical Injuries Compensation Fund, whose number was 252. Sampling was done by stratified random sampling and Morgan Table was used to determine the sample size. The sample size was 148 and 168 questionnaires were distributed among which 20 were defective and incomplete that after removing them according to the number of statistical sample, a valid questionnaire was used for the analysis. The present research's area included Tehran Physical Injuries Compensation Fund. The research was done during December 2018 to June 2019.

\section{Data Collecting Tool}

A questionnaire was used for data collection. Therefore, separate questionnaires were regulated using the Likert Scale and were given to the employees which included a number of questions in the field of measuring the respondents' evaluation of their parameters, attitudes, perceptions, and their characteristics. The questionnaire included planned organizational changes (10 items), professional development (15 items) and empowerment (12 items).

Table 1. Characteristic of the Research Tool Models and Their Dimensions

\begin{tabular}{|l|l|l|l|l|}
\hline Row & Variable & $\begin{array}{l}\text { Name of } \\
\text { Researcher }\end{array}$ & $\begin{array}{l}\text { Research } \\
\text { Year }\end{array}$ & Explanation \\
\hline 1 & $\begin{array}{l}\text { Planned } \\
\text { organizational } \\
\text { changes }\end{array}$ & $\begin{array}{l}\text { Anderson } \\
\text { and } \\
\text { Ackerman }\end{array}$ & 2010 & $\begin{array}{l}\text { According to the model of Anderson and Ackerman, } \\
\text { planned organizational changes had three dimensions: } \\
\text { developmental change, transitional change, and } \\
\text { transformational change }\end{array}$ \\
\hline 2 & $\begin{array}{l}\text { Professional } \\
\text { development }\end{array}$ & $\begin{array}{l}\text { Hejazi and } \\
\text { Rostami }\end{array}$ & 2009 & $\begin{array}{l}\text { According to the model of Hejazi and Rostami, the } \\
\text { professional development variable had three } \\
\text { dimensions of context, content, and the process. }\end{array}$ \\
\hline 3 & Empowerment & Carter & 2001 & $\begin{array}{l}\text { According to the model of Carter, the empowerment } \\
\text { variable had four dimensions of effectiveness, } \\
\text { meaningfulness, competence and choice. }\end{array}$ \\
\hline
\end{tabular}

\section{Reliability and Validity of the Research Tools}

In this research, the questionnaire validity was performed by content validity method. In order to assess the validity of the questionnaire, after adjusting the questionnaire with the original text and applying minor changes in some expressions, their relationship with the measuring factor in measuring the relevant variable in the form of content method was also confirmed by the supervisor and advisor in this study.

Furthermore, Cronbach's alpha test was used to determine the reliability of the questionnaire. The alpha coefficient indicated that the questions were overlapped and also were concurrent and the respondents have answered the questions carefully and consciously.

After distributing 20 questionnaires to the statistical population and then collecting them, the reliability of planned organizational changes, professional development, and empowerment was obtained using SPSS software.

Table 2. Cronbach's Alpha Table

\begin{tabular}{|l|l|}
\hline Variable & Cronbach's alpha \\
\hline Planned organizational changes & 0.88 \\
\hline Professional development & 0.8 \\
\hline Empowerment & 0.78 \\
\hline
\end{tabular}

This value was calculated in the distributed questionnaire for the research variables above $70 \%$, which showed the appropriate reliability of the research.

After completing the questionnaire, the collected data were categorized according to the measurement scales of variables and were analyzed using SPSS software. 


\section{Research Findings}

Descriptive finding, statistical indicators, Kolmogorov- Smirnov test, regression test were used to describe the studies communities, research variables and to respond to research hypotheses.

\section{Descriptive Characteristics of Employee`` Physical Injuries Compensation Fund}

\section{- Frequency of Employees` Gender}

According to Table (3), among the statistical sample, 109 individuals (73.65\%) were male and 39 individuals $(26.35 \%)$ were female.

Table 3. Frequency Distribution of Employees by Gender

\begin{tabular}{|l|l|l|}
\hline Gender & Frequency & Percentage \\
\hline Male & 109 & 73.65 \\
\hline Female & 39 & 26.35 \\
\hline Total & 148 & 100 \\
\hline
\end{tabular}

\section{- Frequency of Employees According to their Marital Status}

- Among the employees of statistical sample, 68 individuals (45.95\%) were single and 80 (54.05\%) were married (Table 4).

Table 4. Frequency Distribution of Employees based on their Marital
\begin{tabular}{|l|l|l|}
\hline Marital status & Frequency & Percentage \\
\hline single & 68 & 45.95 \\
\hline Married & 80 & 54.05 \\
\hline Total & 148 & 100 \\
\hline
\end{tabular}

\section{- Frequency of Employees`Age}

The age distribution of the sample included 6 individuals (4.1\%) under 20, 26 individuals (17.5\%) 20 to 30 years, 60 individuals $(40.54 \%) 31$ to 40 years, 51 individuals $(3.46 \%) 41$ to 50 years and 5 individuals $(3.4 \%)$ were above 51 years old.

Table 5. Frequency Distribution of Employees by Age

\begin{tabular}{|l|l|l|}
\hline Age & Frequency & Percentage \\
\hline Under 20 & 6 & 4.1 \\
\hline $20-30$ & 26 & 17.5 \\
\hline $31-40$ & 60 & 40.54 \\
\hline $41-50$ & 51 & 34.46 \\
\hline Above 51 & 5 & 3.4 \\
\hline Total & 148 & 100 \\
\hline
\end{tabular}

\section{- Frequency of Employees Education}

In terms of education, 5 individuals $(3.38 \%)$ had less degree than diploma, $19(12.84 \%)$ had diploma and associate degree, 76 (51.35\%) had bachelor degree, 44 (29.73\%) had master degree and $4(2.7 \%)$ also had PhD degree (Table 6).

Table 6. Frequency Distribution of Employees based on Education

\begin{tabular}{|l|l|l|}
\hline Education & Frequency & Percentage \\
\hline Less than diploma & 5 & 3.38 \\
\hline Diploma and associate degree & 19 & 12.84 \\
\hline Bachelor degree & 76 & 51.35 \\
\hline Master degree & 44 & 29.73 \\
\hline PhD & 4 & 2.7 \\
\hline Total & 148 & 100 \\
\hline
\end{tabular}




\section{Statistical Indicators of Research Variables}

Statistical indicators such as mean, variance, and standard deviation of research variables are presented in Table 7. With regard to the averages, the respondents had a relatively close opinion in the most of variables.

Table 7. Descriptive Statistics of Research Variables

\begin{tabular}{|l|l|l|l|l|}
\hline Variable & $\begin{array}{l}\text { Number } \\
\text { of items }\end{array}$ & Mean & $\begin{array}{l}\text { Standard } \\
\text { deviation }\end{array}$ & Variance \\
\hline $\begin{array}{l}\text { Planned organizational } \\
\text { changes }\end{array}$ & 10 & 2.944 & 0.563 & 0.318 \\
\hline $\begin{array}{l}\text { Professional } \\
\text { development }\end{array}$ & 15 & 3.086 & 0.57 & 0.325 \\
\hline $\begin{array}{l}\text { Employees } \\
\text { empowerment }\end{array}$ & 12 & 2.992 & 0.605 & 0.366 \\
\hline
\end{tabular}

\section{Inferential Findings}

In this research, the research questions and their responses were analyzed by statistical methods. Therefore, Kolmogorov-Smirnov test was used to check whether the research variables were normal or not (Table 8).

Table 8. Kolmogorov-Smirnov Test Results for the Research Variables

\begin{tabular}{|l|l|l|l|}
\hline Variable & Statistic & Significance level & Result \\
\hline $\begin{array}{l}\text { Planned organizational } \\
\text { changes }\end{array}$ & 0.795 & 0.533 & It is normal \\
\hline $\begin{array}{l}\text { Professional } \\
\text { development }\end{array}$ & 0.649 & 0.794 & It is normal \\
\hline $\begin{array}{l}\text { Employees } \\
\text { empowerment }\end{array}$ & 0.922 & 0.35 & It is normal \\
\hline
\end{tabular}

\subsection{Testing First Hypothesis}

Hypothesis: The extent of planned organizational changes has an impact on the professional development of employees of physical injuries compensation fund.

Table 9. The Summary of Regression Model for Hypothesis 1

\begin{tabular}{|l|l|l|l|}
\hline $\begin{array}{l}\text { Correlation } \\
\text { coefficient }\end{array}$ & $\begin{array}{l}\text { Determination } \\
\text { coefficient }\end{array}$ & $\begin{array}{l}\text { Adjusted R Square } \\
\text { coefficient }\end{array}$ & $\begin{array}{l}\text { Durbin- } \\
\text { Watson }\end{array}$ \\
\hline 0.635 & 0.403 & 0.399 & 1.752 \\
\hline
\end{tabular}

According to the mentioned results, the correlation coefficient between the extent of planned organizational changes and the professional development of the employees of physical injuries compensation fund was 0.635 and the determination coefficient was 0.403. If the Durbin-Watson statistic was placed between the acceptable range of 1.5 to 2.5 , the discrepancy between the errors would be accepted. Since the Durbin-Watson statistic was 1.752 , it can be said that the discrepancy between errors was accepted.

Table 10. Results of One-way Variance Analysis for Hypothesis 1

\begin{tabular}{|l|l|l|l|l|l|}
\hline & $\begin{array}{l}\text { The sum of } \\
\text { squares }\end{array}$ & $\begin{array}{l}\text { Freedom } \\
\text { degree }\end{array}$ & $\begin{array}{l}\text { The average } \\
\text { of squares }\end{array}$ & F & $\begin{array}{l}\text { Significance } \\
\text { level }\end{array}$ \\
\hline Regression & 19.464 & 1 & 19.264 & 98.501 & 0.000 \\
\hline Discrepancy & 28.553 & 146 & 0.196 & - & - \\
\hline Total & 47.817 & 147 & - & - & - \\
\hline
\end{tabular}

According to the results of the above Table and with regard to the significance level of the test error (f), the confidence level of 0.99 was less than 0.01 , so it can be said that the independent variable could predict the dependent variable. 
Table 11. The Results of Univariate Regression Coefficient for Hypothesis 1

\begin{tabular}{|l|l|l|l|l|l|}
\hline \multirow{2}{*}{ Predictive variable } & \multicolumn{2}{|l|}{$\begin{array}{l}\text { Non-standard } \\
\text { coefficients }\end{array}$} & $\begin{array}{l}\text { Standard } \\
\text { coefficients }\end{array}$ & T & P \\
\cline { 2 - 4 } & $\mathrm{B}$ & $\mathrm{SE}$ & BETA & & \\
\hline Constant value & 1.195 & 0.194 & - & 6.159 & 0.000 \\
\hline $\begin{array}{l}\text { The extent of planned } \\
\text { organizational changes }\end{array}$ & 0.642 & 0.065 & 0.635 & 9.925 & 0.000 \\
\hline
\end{tabular}

According to the results of Table (11) and since the significance level of the test error was less than 0.01 , so it can be said that the first main hypothesis was confirmed and the planned organizational changes had a significant positive effect on the professional development of the employees of physical injuries compensation fund. In addition, the beta coefficient showed that the planned organizational changes predicted 0.635 of changes in the employees' professional development.

3.2. Multivariate Regression Test for Examining the Impact of Planned Organizational Change Dimensions on the Professional Development of Employees

Table 12. Summary of Regression Model

\begin{tabular}{|l|l|l|l|}
\hline $\begin{array}{l}\text { Correlation } \\
\text { coefficient }\end{array}$ & $\begin{array}{l}\text { Determination } \\
\text { Coefficient }\end{array}$ & $\begin{array}{l}\text { Adjusted R square } \\
\text { coefficient }\end{array}$ & $\begin{array}{l}\text { Durbin- } \\
\text { Watson }\end{array}$ \\
\hline 0638 & 0.407 & 0.395 & 1.76 \\
\hline
\end{tabular}

The results of Table (12) showed that the correlation coefficient between the dimensions of planned organizational changes with the professional development of the employees of the physical injuries compensation fund was 0.938 (the correlation coefficient is significant) and the determination coefficient was 0.407 , and Durbin-Watson statistic was 1.76. So, it can be said that non-correlation between the errors was accepted.

Table 13. The Results of One-way Variance Analysis

\begin{tabular}{|l|l|l|l|l|l|}
\hline & $\begin{array}{l}\text { Sum of } \\
\text { squares }\end{array}$ & $\begin{array}{l}\text { Freedom } \\
\text { degree }\end{array}$ & $\begin{array}{l}\text { Average of } \\
\text { squares }\end{array}$ & F & $\begin{array}{l}\text { Significance } \\
\text { level }\end{array}$ \\
\hline Regression & 19.48 & 3 & 6.493 & 32.996 & 0.000 \\
\hline Remainder & 28.338 & 144 & 0.197 & - & - \\
\hline Total & 47.817 & 147 & - & - & - \\
\hline
\end{tabular}

With regard to the significance level of f-test error, it can be said that using linear regression model to examine the dimensions of planned organizational changes with professional development of the employees of physical injuries compensation fund was permissible, or in other words, the independent variables had the ability to predict the dependent variable.

Table 14. Multivariate Regression Coefficient Results

\begin{tabular}{|l|l|l|l|l|l|}
\hline \multirow{2}{*}{ Predictive variable } & \multicolumn{2}{|l|}{$\begin{array}{l}\text { Non-standard } \\
\text { coefficients }\end{array}$} & $\begin{array}{l}\text { Standard } \\
\text { coefficients }\end{array}$ & \multirow{2}{*}{$\mathrm{T}$} & $\mathrm{P}$ \\
\cline { 2 - 5 } & $\mathrm{B}$ & $\mathrm{SE}$ & BETA & & \\
\hline Constant value & 1.195 & 0.195 & - & 6.137 & 0.000 \\
\hline Developmental change & 0.208 & 0.057 & 0.263 & 3.648 & 0.000 \\
\hline Transitional change & 0.249 & 0.068 & 0.301 & 3.668 & 0.000 \\
\hline Transformational change & 0.186 & 0.62 & 0.235 & 2.991 & 0.003 \\
\hline
\end{tabular}

By considering Table (14), it can be said that the "transition change" dimension with a beta coefficient of 0.301 had the highest predictive power for the dependent variable (professional development of the employees of physical injuries compensation fund), and then the "developmental change" dimension with a beta coefficient of 0.263 and also "transformational change" dimension with a beta coefficient of 0.235 predicted the professional development of the employees of physical injuries compensation fund. 


\subsection{Second Main Test}

Hypothesis: The extent of planned organizational changes has an impact on the empowerment of the physical injuries compensation fund.

Table 15. Summary of Regression Model for Hypothesis 2

\begin{tabular}{|l|l|l|l|}
\hline $\begin{array}{l}\text { Correlation } \\
\text { coefficient }\end{array}$ & $\begin{array}{l}\text { Determination } \\
\text { Coefficient }\end{array}$ & $\begin{array}{l}\text { Adjusted R square } \\
\text { coefficient }\end{array}$ & Durbin-Watson \\
\hline 0.75 & 0.563 & 0.56 & 1.637 \\
\hline
\end{tabular}

The correlation coefficient between the extent of planned organizational changes and the empowerment of the employees of the physical injuries compensation fund was 0.75 , and the determination coefficient was 0.563 and the Durbin-Watson statistic was 1.637 (Table 15), so it can be said that discrepancy between the errors was accepted.

Table 16. The Results of One-way Variance Analysis for the Hypothesis 2

\begin{tabular}{|l|l|l|l|l|l|}
\hline & Sum of squares & Freedom degree & $\begin{array}{l}\text { Average } \\
\text { of squares }\end{array}$ & F & $\begin{array}{l}\text { Significance } \\
\text { level }\end{array}$ \\
\hline Regression & 30.326 & 1 & 30.326 & 188.091 & 0.000 \\
\hline Discrepancy & 23.54 & 146 & 0.161 & - & - \\
\hline Total & 53.886 & 147 & - & - & - \\
\hline
\end{tabular}

The results of the above table showed that the significance level of the f-test error for the confidence level of 0.99 was less than 0.01 , so it can be said that the independent variable could predict the dependent variable.

Table 17. Univariate Regression Coefficient Results for Hypothesis 2

\begin{tabular}{|l|l|l|l|l|l|}
\hline Predictive variable & \multicolumn{2}{|l|}{$\begin{array}{l}\text { Non-standard } \\
\text { coefficients }\end{array}$} & $\begin{array}{l}\text { Standard } \\
\text { coefficients }\end{array}$ & T & P \\
\cline { 2 - 5 } & $\mathrm{B}$ & SE & BETA & & \\
\hline Constant value & 0.619 & 0.176 & - & 3.513 & 0.000 \\
\hline $\begin{array}{l}\text { The extent of planned } \\
\text { organizational changes }\end{array}$ & 0.806 & 0.059 & 0.75 & 13.715 & 0.000 \\
\hline
\end{tabular}

According to Table (17), the main hypothesis 2 was confirmed and the extent of planned organizational changes had a significant positive effect on the employees' empowerment of the physical injuries compensation fund. In addition, the beta coefficient showed that the extent of planned organizational changes predicted 0.75 of the employees' empowerment changes.

3.4 Multivariate Regression Test for Examining the Impact of Dimensions of Planned Organizational Changes on Employee Empowerment

Table 18. Summary of Regression Model

\begin{tabular}{|l|l|l|l|}
\hline $\begin{array}{l}\text { Correlation } \\
\text { coefficient }\end{array}$ & $\begin{array}{l}\text { Determination } \\
\text { Coefficient }\end{array}$ & $\begin{array}{l}\text { Adjusted R square } \\
\text { coefficient }\end{array}$ & $\begin{array}{l}\text { Durbin- } \\
\text { Watson }\end{array}$ \\
\hline 0.764 & 0.583 & 0.575 & 1.737 \\
\hline
\end{tabular}

According to the above Table, the correlation coefficient between the dimensions of planned organizational changes with the empowerment of the employees of physical injuries compensation fund was 0.764 (correlation coefficient is significant) and the determination coefficient was 0.583 and Durbin-Watson statistic was 1.737 , so it can be stated that non-correlation between the errors was accepted.

Table 19. One-way Variance Analysis Results

\begin{tabular}{|l|l|l|l|l|l|}
\hline & Sum of squares & Freedom degree & Average of squares & F & Significance level \\
\hline Regression & 31.419 & 3 & 10.473 & 67.184 & 0.000 \\
\hline Remainder & 22.447 & 144 & 0.156 & - & - \\
\hline Total & 53.866 & 147 & - & - & - \\
\hline
\end{tabular}


According to Table 19, using linear regression model for examining the dimensions of planned organizational changes by empowering the employees of the physical injuries compensation fund was permissible or in other words, the independent variables had the ability to predict the dependent variable.

Table 20. Multivariate Regression Coefficient Results

\begin{tabular}{|l|l|l|l|l|l|}
\hline Predictive variable & \multicolumn{2}{|l|}{$\begin{array}{l}\text { Non-standard } \\
\text { coefficients }\end{array}$} & $\begin{array}{l}\text { Standard } \\
\text { coefficients }\end{array}$ & T & P \\
\cline { 2 - 4 } & B & SE & BETA & & \\
\hline Constant value & 0.602 & 0.173 & - & 3.472 & 0.001 \\
\hline Developmental change & 0.29 & 0.051 & 0.345 & 5.705 & 0.000 \\
\hline Transitional change & 0.137 & 0.061 & 0.156 & 2.265 & 0.025 \\
\hline Transformational change & 0.381 & 0.055 & 0.453 & 6.871 & 0.000 \\
\hline
\end{tabular}

According to Table (20), it can be said that the "transformational change" dimension with the beta coefficient of 0.453 had the highest predictive power of the dependent variable (employee empowerment of the physical injuries compensation fund), and after that "developmental change" dimension with beta coefficient of 0.345 and also "transitional change" dimension with beta coefficient of 0156 were placed, which predicted the employees' empowerment of the physical injuries compensation fund.

\section{Conclusion and Suggestions}

\section{Conclusion}

According to the results and since the significance level was greater than 0.05 , all the studied variables followed the normal distribution and it was necessary and sufficient to use parametric statistics. With regard to the given explanations and the Kolmogorov-Smirnov test table, the egression test was selected and the research hypotheses were tested.

First hypothesis: The planned organizational changes impacts the professional development of the employees of physical injuries compensation fund.

The results of the research confirmed this hypothesis. The results of this hypothesis were consistent with the studies of Tatari Balehsur (2018), Ariana et al. (2017), Roshanfekr and Daneshfard (2016), Zand (2014), Taheri et al., (2013), Tofighi et al. (2013), Aron (2013), and Sopamot (2011). To explain this hypothesis, it can be said that if organizations want to survive in the competitive area, they must constantly adapt themselves to the external environment. The organizational change does not happen without any preliminaries. The change drivers usually originate from the organizational environment or market. These drivers include cases like bold moves of the competitors, new technology, or changes in the government regulation. In addition, inefficiencies of the manager can be a trigger for change in the organization. Professional development also occurs when the organizations provide the necessary opportunity through improving educational, economic, managerial, and environmental conditions for promoting skills and knowledge related to employee activities. Therefore, the main point of measuring professional development is to have necessary conditions and spaces for employees to develop and learn new skills.

Second hypothesis: The planned organizational changes impact the empowerment of employees of the physical injuries compensation fund.

The second hypothesis of the study was confirmed by the results. The results of this research were consistent with the studies of Tayebi Shirmard and Mirzaei (2018), Tatari Balehsouri (2018), Ariana et al. (2017), Zahed et al. (2017), Roshanfekr and Daneshfard (2016), Niknami and Zaremoyedi (2016), Aminbidokhti and Ghiasuddin (2016), Tofighi et al. (2014), Vaezi and Sabzikaran (2011), Karimian et al. (2011), Karz et al. (2017), Dewettinck et al. (2013), and Ledez (2010). To explain this hypothesis, it can be said that empowerment is a new way for organizations to continue working toward their organizational goals. Empowerment is the process of empowering the individuals. Empowering the employees has positive effects on employees' attitudes and behaviors. Therefore, in the current situation, organizations have no choice except properly utilizing human resources as a competitive advantage. One of the most influential factors in establishing different dimensions of empowering process is the planned organizational changes. The importance of organizational changes in shaping organizational processes (especially methods of developing human resources in the organization) needs more attention regarding the relationship and its effects on the process of empowering employees. 


\section{Suggestions}

According to the results of the research the following suggestions are presented:

1. The organization, by participating the members in determining the future direction of their wok unit, can make them have a better performance and by respecting the value of their work in the organization can create a sense of membership in the employees.

2. It is suggested that the performance feedback system be strengthened in the organization and the manager respond to the feedback of employees' behavior to adapt them to organizational processes and reforms, which can be effective in improving organizational health.

3. Managing the physical injuries compensation fund with the help of experts and professionals should create an atmosphere in the organization that people feel a sense of belonging to the organization.

4. Managing the physical injuries compensation fund with the help of experts and professionals should provide the employees with necessary trainings to acquire new knowledge and skills that they need to do their duties.

5. It is suggested that the managers can develop their competencies and acquire the necessary skills for the plans of employee empowerment processes, since managers are the starting point of the empowerment process. Therefore, the managers and planners of physical injuries compensation fund should plan and execute appropriate training courses for the managers of such businesses and be able to generate new ideas and opinions about the existing phenomena.

6. The management of physical injuries compensation fund must be able to adapt itself to the changes, see the positive dimensions of different positions, and respond effectively to new information or changes occurring in a particular situation.

\section{References}

[1] Anderson, D., \& Ackerman, A. L.(2010). Beyond change management: advance strategies for today's transformational leaders. 14(5):104-114.

[2] Aron, S (2013)."Definition of faculty development, Pod net workprofessional and organizational network in higher education ". 9(1),100112 .

[3] Caers, R., Bois, C.D., Jegers, M., Gieter, S.D., Cooman, R.D. and Pepermans, R A.(2017),micro-economic perspective on manager selection in nonpro.t organizations. European Journal of Operational Research: Article in press,accepted. 52(2): 247-114.

[4] Carter, M. (2001). Strategic planning (in nonprofit or for profit organizations), Journal of educational administration, 5(3): 37- 49.

[5] Dewettinck, K., Singh, J. and Buyens, D. (2013). "Psychological empowerment in the workplace". reviewing the empowerment effects on critical work outcomes, vlerick leuven gent management schoo 122(4): 411- 436.

[6] Ledez,R.E.(2011). “Change management: Getting a Tuned up organization" 1(1):120-128.

[7] Robbins, M., Crino, D. \& Fredendall. L. (2002). An integrative model of the empowerment process, Journal of Human Resource management, 12(1): 419-443.

[8] Soparnot, R.D.(2011).” The concept of organizational change capacity" Journal of Organizational Change Management,24(5):640-661.

[9] Amin Bidokhti, Ali Akbari. (2015). Investigating Factors Affecting Employee Empowerment (Case Study: Semnan Cooperative, Labor and Social Welfare Offices), Investigating Factors Affecting Employee Empowerment (Case Study: Provincial Cooperation, Labor and Social Welfare Department) Semnan), Social, Economic, Scientific and Cultural Journal of Work and Society, 182: 31-36.

[10] Ariana, Azadeh; Reza Ameri Sihuei and Tahereh Mahmoudi. (2017).Investigating the Relationship between Empowerment of Personnel and Professional Development at FatemiehTechnical School in Bandar Abbas, International Conference on Management and Resistance Economics, Malaysia, Iran Modern Meta Development Center.

[11] Tattari Balehsour, Esmail. (2018). Investigating the Relationship between Supervision and Guidance of Managers with Professional Development, Accountability, and Psychological Empowerment of Teachers of Secondary Male High School in Urmia during 20172018 , Master Thesis of educational management, Faculty of Letters and Humanities of the University of Urmia.

[12] Tofighi Shahram, Chagheri, Mahmood, Amerion, Ahmad and Karimizarchi, Ali Akbar. (2013). The Effect of Organizational Changes on Organizational Health Indicators and Its Relationship with Organizational Effectiveness; Journal of Military Medicine, 13(3): 173179.

[13] Hejazi, Youssef, Pardakhtchi, Mohammad Hassan and Shahpasand, Mohammad Reza .(2011). Teacher Professional Development Approaches, First Edition: Tehran, Tehran University Press Institute.

[14] Roshanfekr, Ehsan and Karamollah Danesh Fard.( 2016). Investigating the Relationship between Planned Organizational Changes and Empowerment of Yasuj University Personnel, International Conference on Management, Economics and Industrial Engineering, Tehran, Thinker Managers Institute of Vira Capital.

[15] Zahed, Adel, Namvar, Yousef and Nobakht, Shahram. (2016). The Relationship between Perceived Organizational Support and Empowerment and Self-efficacy of Meshginshahr Teachers in the Academic Year2015-2016, Journal of Education and Evaluation (Educational Sciences), 2 (8): 107-128.

[16] Zand, Azita. (2013). Investigating the Factors Affecting the Development of Experts in Islamic Azad University of Islamshahr Branch, Journal of Educational Leadership and Management, 5(2): 72-52.

[17] Taheri, Morteza, Arefi, Mahboubeh, Pardakhtchi, Mohammad Hasan \& Ghahramani, Mohammad. (2013). Exploring the Process of Teacher Professional Development in Teacher Training Centers: Grounded Theory, Journal of Educational Innovation, 12(45:176-149.

[18] Tayibi Shirmard, Mehdi and Mirzaei, Noor al-Din. (2018). Investigating the Relationship between Organizational Structure and Empowerment of Employees of Tehran Municipality Management Development Deputy, Urban Management Studies Quarterly, 9(29): 70-72.

[19] Karimian, Jahangir, Shakarchizadeh Isfahani, Parivash and Yarmohammadian, Mohammad Hossein. (2010). The Impact of Organizational Change on Staff Response of Isfahan University of Medical Sciences, Health Information Management, 7: 586-593.

[20] Majidi, Abdullah. (2008). Investigating the Impact of Displacement on Job Satisfaction and Organizational Commitment of Employees, Master Thesis of Management, Tarbiat Modarres University, Tehran. 
[21] Nobakht, Mohammadbagher, Mazaheri, Mohammad Mehdi and Isfahani, Mina .(2013). Presentation of Human Resources Empowerment Model in Cultural Organizations (Case Study: Cultural and Artistic Organization of Tehran Municipality), Journal of Cultural Management, 7(19): 87-71.

[22] Niknami, Mustafa and Zare Moaydi, Hussein. (2015). Organizational Intelligence and its Role in Promoting Employee Empowerment, Isfahan University of Humanities Research, 31:155-174.

[23] Vaezi, Reza and Sabzikaran, Esmail .(2010). Investigating the Relationship between Organizational Change and Empowerment of Personnel in National Iranian Oil Products Distribution Company - Tehran Region, Revolution Management Research Journal, 2(3): 153-187. 